\title{
Chapter 4 \\ Emigration from Italy After the Crisis: \\ The Shortcomings of the Brain Drain \\ Narrative
}

\author{
Guido Tintori and Valentina Romei
}

In this chapter, we try to assess whether the international economic crisis, which stemmed from the credit crunch of 2007-2008 originated in the United States and the United Kingdom, has had a significant impact on Italy's migratory patterns. According to official statistics, Italy has steadily had a positive net migration since 1974, thus turning into a 'country of immigration', after a long-standing status of a 'country of emigration'. This turn in Italy's migratory balance should not convey the idea, though, that there have not been relatively significant numbers of people leaving the country even after the 1970s (Tintori 2013: 127-133). In our analysis, we focus our attention primarily on outflows from Italy towards Northern Europe, testing the conventional assumption that the country, in a sort of path dependent response, recurred to emigration as a viable remedy to economic strain and as a safety valve to release the social pressure of high level of unemployment. In the first part of the chapter, we initially consider the evolution of the financial, economic and social conditions of the country from the 1990s to 2015. We then provide a brief historical review of the migratory flows from and to Italy for the same period. This basic overview of the interaction of the economic crisis and Italy's migratory patterns works as a background to discuss more specific questions concerning current emigration: its scale, compared to past experiences; its composition, with special attention paid to the level of professional skills, sex and age; the reliability of available data. To describe in detail the socio-demographic profile of the Italian emigrants since the 2000s and their destinations we rely on Italian data collected by the ministries of the Interior and Foreign Affairs, as well as by the National statistical office (ISTAT). We critically assess the accuracy of such data against the available statistical sources from the top destination countries. In the second part of the

\author{
G. Tintori $(\bowtie)$ \\ FIERI International and European Forum on Migration Research, Turin, Italy \\ e-mail: guido.tintori@fulbrightmail.org \\ V. Romei \\ Statistical journalist at the Financial Times, London, UK
}


chapter, we analyse both the public discourse on and the policy response to the most recent outflows. In particular, we look at how the political elites discursively framed the relationship between the crisis and the outflows and to what extent the most recent outflows intertwine with the latest labour market reforms. In conclusion, we fact-check whether the hegemonic narrative focusing on the 'brain drain' is consistent with the data on the human capital of those who have left and might leave.

\subsection{A Quantitative Approach to Crisis-Induced Emigration from Italy}

\subsubsection{Current Economic and Social Situation}

Since the 1990s, the Italian economy has been suffering from a long period of sluggish or no growth. After 2007, Italy faced a series of dip recessions, which resulted in a rapid deterioration of the quality of life of her population.

The reasons behind the country's poor economic performance since the 1990s are numerous and controversial ranging from its public debt, a sclerotic bureaucracy, low productivity rates and falling competitiveness - mainly linked to relatively high unit labour costs, excessive regulation, lack of R\&D spending, an excess of small sized businesses -, political instability, inefficiency, corruption and uncompetitive marketable services (Ciocca 2007: Ch. 12 \& 13). The 2008 international crisis, therefore, hit Italy in a peculiar way, compared to other Eurozone countries, making recovery less a question of cutting expenses and bailing out the financial and bank system, than a demand for far-reaching structural reforms of the public sector and the business environment (Ciocca 2010). The international crisis of 2008 aggravated, if anything, the political and economic instability Italy has been struggling with since the early 1990s.

While all the Eurozone had a double digit growth in the last 15 years, the Italian economy did not grow at all. It grew very slowly even in the first half of 2000 when the Spanish economy, for example, rose by $17 \%$. After the crisis, even though Italy avoided any bank bailouts and the direct intervention of the European Commission (EC), the European Central Bank (ECB) and the International Monetary Fund (IMF) - the so-called 'Troika' - the country's recovery has been very weak. Compared to the same period in 2008, Italy's economy still shrank the most among both core countries - France, the UK and Germany - and some peripheral countries, including Spain, in the second quarter of 2015. Italy's was the only one to contract in 2014 among major European economies, and in the first half of 2015 it grew at half the speed of the average of the Eurozone. In the 2 years to the second quarter of 2015 the Italian GDP rose by a meagre $0.4 \%$, while the UK gained $5.7 \%$. Whatever the main reasons of "steady and prolonged decline in growth" (Tiffin 2013: 3) the consequences included lost of employment, productivity, output, savings, impoverishment of its population and lack of confidence. 
Unemployment levels started to slowly decline in 2015 but, at just below $12 \%$ of the population, they still are close to the all-time high since the 1960s. Both the EC and the IMF forecast the level to remain above the country long-term average until 2020. In Italy the level of unemployment is still much lower than in other Southern European countries - in Spain and Greece it varies between $22 \%$ and $25 \%$ - but it also hides a more general deterioration of the labour market (Ballestrero 2012; Carinci 2012). As in Italy it is relatively difficult to dismiss employees, especially in the public sector, there has been an increase of poor quality employment and unemployment among the most vulnerable groups, like the youth. According to Eurostat (2015) Italy's youth unemployment reached $41 \%$ in August 2015, the third largest in the Eurozone after Greece (48\%) and Spain (49\%). Both youth and total unemployment rates are higher among the female population. The crisis resulted in a narrowing of the gender gap in employment rates among all advanced countries. In Italy, this kind of convergence takes place at a slower pace, in that a higher proportion of women in working age were inactive, mainly because of a lack of job opportunities and rewarding careers. This is particularly worrying, as according to OECD nearly half of the Italian female population (45\%) is inactive, the third largest proportion after Turkey and Mexico. The same source shows that Italy has the second largest proportion among advanced countries after Chile for marginally attached workers, i.e. people not in the labour force because they were too discouraged to look for jobs, but willing and available to work. It also ranks third among advanced economies after Spain and the Slovak Republic for proportion of people that are working part-time because they could not find a full time job.

Over $25 \%$ of total employees in Italy are self-employed, the second highest proportion in Western Europe after Greece. The figure is, to some extent, inflated by the fact that many self-employed are de facto working full time for a different employer, since there is a lower tax wedge for independent contractors. Still, self-employment can also be seen as a survival strategy for those who cannot find any other means of earning an income. Those who do find jobs are employed with largely precarious contracts. According to the OECD more than half of the youth (15-24 years old) were in temporary contracts in 2014. Despite the current government's claims on the positive impact of the recently approved "jobs act", only one third of the new contracts registered between January and July 2015 were permanent. ${ }^{1}$ On the other side, those that are unemployed tend to be so for a long period with the risk of having rising difficulties in re-entering the labour market. Nearly $60 \%$ of the unemployed in Italy have been so for more than 1 year, the fifth largest among OECD countries and a rapid rise from $49 \%$ before the crisis.

The result is that real disposable income has been rapidly deteriorating and it is now at lower levels than in the early 1990s, while it is over $60 \%$ higher in the Eurozone. The deterioration of the labour market, in fact, is much more evident from data on poverty rather than from unemployment rates. According to Eurostat,

\footnotetext{
${ }^{1}$ Source: http://www.inps.it/bussola/VisualizzaDOC.aspx?sVirtualURL=/docallegati/DatiEBilanci /osservatori/Documents/Osservatorio_Precariato_Gen-Lug2015.pdf\&iIDDalPortale=10156. Accessed 1 October 2015.
} 
the percentage of the population that is severely deprived is much higher in Italy than in other Western European countries $(11.5 \%$ in 2014 vs. $7.1 \%$ in Spain and $5 \%$ in France and Germany). The percentage declined from its peak at $14 \%$ in 2012, but it's still double than the pre-crisis period (Eurostat 2013).

\subsubsection{Migratory Dynamics Before and During the Economic Crisis}

Since the 2000s, Italy, together with Greece, Spain and the United Kingdom, has been one of the main immigrant-receiving countries in Europe (OECD 2011: 403404). The international economic crisis has, of course, impacted on Italy's migratory dynamics. The country still attracts significant numbers of immigrants, mainly because the backbone of its productive system, made of small and medium enterprises, is in labour-intensive sectors, like fashion, agriculture and food. Italy thus continues to present a positive net migration, even though the gap between those who enter and those who leave the country every year has been shrinking, especially since 2011. Total immigration into the country, i.e. including Italian returnees, went from roughly 527,000 individuals at its peak in 2007 to almost 307,000 in 2013. Despite this decrease, yet official data show that the net international migration amounted to considerable $+142,000$ units in 2014, $+182,000$ in 2013 and $+245,000$ in 2012. On the other hand, total emigration, i.e. including foreigners leaving the country, for the same period has doubled, passing from nearly 51,000 in 2007 to over 139,000 in 2014 (ISTAT 2015, 2014).

Focussing on Italian citizens only, there is a clear growing trend of Italian nationals moving their residency abroad. The 2014 and 2013 figures - respectively, 89,000 and 82,000 - are the highest in the last 10 years (ISTAT 2014, 2015). The net migration of Italian citizens has been negative already for most of the 1990s and 2000s but since 2009 the gap is widening. Nonetheless, according to ISTAT, the number of Italian emigrants has not reached yet the levels of the 1970s.

High rates of returns, a typical trait of historical emigration from Italy, are a feature of more recent emigration patterns too. ${ }^{2}$ The numbers of Italians returning to their home country, though, are lower than they used to. For example, the nonforeign population that moved to Italy from abroad in 2012 was $20 \%$ lower than in 2007. In the 5 years to 2012, 28,000 Italian nationals moved to Italy from Germany, the same number in the previous 5 years was over 51,000. Over the same period, Italians returning from Switzerland dropped from 24,000 to 13,000. According to Eurostat, in 2012 Italy had the smallest share of returning migrants among all European countries (excluding Cyprus and Luxemburg).

The foreign population residing in Italy is increasingly leaving the country. Over 11,000 Romanians - the largest foreign-born national group in Italy - left the

\footnotetext{
${ }^{2}$ For a thorough discussion of past Italian emigrations - destinations, volumes, patterns (return or settlement) and political contexts - see (Tintori 2013).
} 
country in 2013 together with nearly 2400 Moroccans and a similar number of Albanians. At the same time, the annual inflow of the same groups is declining. It needs also to be considered that documented immigrants leaving the country have no incentives - just as natives - to de-register as residents in Italy, since it would involve loosing some benefits there, such as access to welfare service and public health care. For example, while ISTAT counted about 1500 Albanians leaving Italy in 2011, the Albanian statistics registered nearly 7000 Albanian returnees from Italy for the same year. The explanation in the mismatch of the two data, apart from possible differences in collecting them, lies also in the above-mentioned reason.

\subsubsection{Main Trends in the Current Emigration}

As everyone who has familiarity with the collection of data on international mobility knows, it is difficult to say exactly how many people are leaving or entering Italy every year. Undocumented immigration is a known problem, but undetected emigration is also an issue. Italians living abroad have a legal obligation to register in the AIRE (Registry of the Italian citizens residing abroad) at consulates, provided they have the intention of staying in that country for at least 12 month. There are no real incentives to register, since failure to comply with the law is not sanctioned and, once registered into the AIRE, the citizens lose a series of benefits in the home country, such as their access to the health service of their region of last residence, to name one. In addition, most people might not know for how long they are going to stay abroad, especially when they move to another EU member state with temporary contracts or as jobseekers. Therefore, Italians abroad register only when they are in need of a service from the consulate, typically, after quite some time. Therefore, AIRE figures are, on the one hand, very likely to underestimate the presence of Italian workers abroad, especially when their stay is temporary. Despite that, the most recent data of the AIRE show that the stock of citizens officially residing abroad has increased impressively in the last decade and totalled more than 4.5 million nationals at the end of 2014 (see Fig. 4.1). Yet, according to AIRE data less than one in four Italian residents abroad is aged between 18 and 34; a proportion that has remained unchanged from before the crisis. Once again, AIRE figures prove they are not a useful source to understand current outflows from Italy, since they include not only people who emigrated a long time ago, people born to Italian parents abroad, but most of all sizeable amounts of people who were born outside Italy and obtained citizenship by descent. According to the latest available data, in fact, between 1998 and 2010 at least 1,003,403 individuals got Italian citizenship by descent at Italian consulates abroad and were automatically added to the AIRE registry. $73.3 \%$ of the total new Italian/EU passports were released in Latin American countries (Tintori 2009, 2012).

At the same time, the ISTAT data too, based on the changes of residence administrative source, under-estimate the real-time emigration flows, since they detect only the individuals that officially move their abode overseas. However, they still 


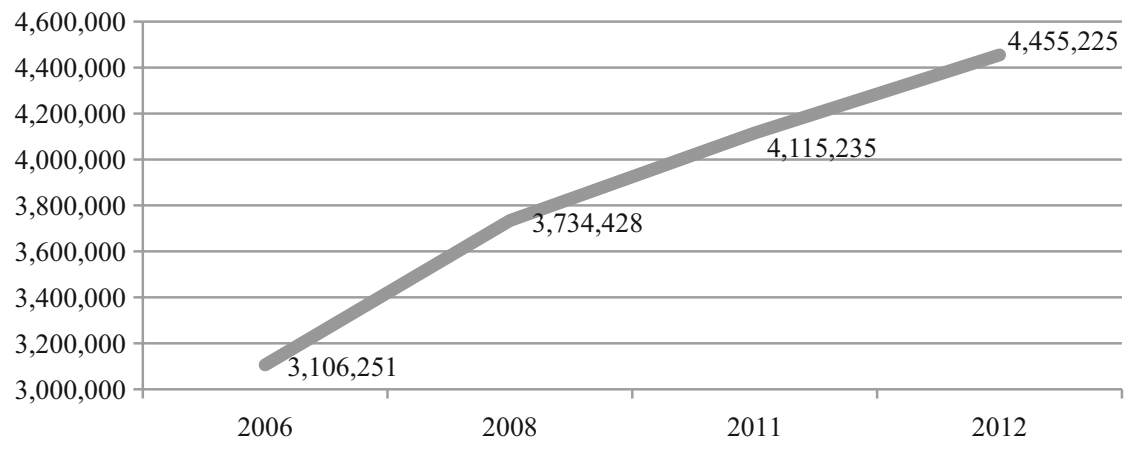

Fig. 4.1 Italian residents abroad 2006-2013 (Source: AIRE)

seem to be the best Italian source available to grasp the trends in current emigration. According to ISTAT, over 320,000 people left Italy between 2009 and 2012, $40 \%$ more than the previous 4 years. Contrary to the conventional wisdom that holds that almost exclusively southerners contributed to Italian emigration, the majority of the recent emigrants came from the northern regions of Italy. In absolute terms, the largest flow of nationals emigrating from Italy in 2012 was to Germany, Switzerland, the UK and France. In 2013, for the first time the UK took over as the most favoured destination, followed by Germany, Switzerland and France. The data on the 2014 flows confirm the UK as a booming destination (see also Chap. 10). The average age was around 34 years old and there was a prevalence of males $(57.6 \%)$ over females (ISTAT 2014). The percentage of graduates on the emigrant population above 25 years of age has increased from $11.9 \%$ in 2002 to $30.6 \%$ in 2013 . The increase of graduates among the emigrants is somehow expected, given the high competition for jobs in the international labour market, especially in the destination countries privileged by Italian graduates. The top five countries that attracted the highest percentage of highly educated Italians were, in 2013, the US (35\%), UK $(33.9 \%)$, Brazil (32.2\%), Switzerland (30.7\%), Spain (30.3\%). There is therefore a growing trend of graduates leaving the country, but the share is still by far a minority of the emigrant population. In the second part of the chapter, we will analyse better whether Italy is currently affected by a "brain drain" or not (Table 4.1).

\subsubsection{Main Destination Countries}

As showed, according to ISTAT, the largest flow of nationals emigrating from Italy in 2013 was to the UK (almost 14,000) followed by Germany $(11,400)$, Switzerland and France (around 8000-9000 to each country). In all those countries, between 2010 and 2013, the rise of emigration flow from Italy was the fastest since the mid1990s. Once again, data should be taken as a source to grasp the magnitude or trends of current emigration, not as a source of precise information. Looking at destination countries' data, therefore, might help, but even in this case we should put the data in perspective. 
Table 4.1 \% of Italian resident population (15-64) and emigrants (25-64) by educational attainment, 2002-2013

\begin{tabular}{l|l|l|l|l}
\hline \multirow{2}{*}{} & $\begin{array}{l}\text { Resident population } \\
(15-64)\end{array}$ & \multicolumn{3}{l}{} \\
\cline { 2 - 5 } & Italian emigrants (25-64) & $\begin{array}{l}\text { Secondary/higher } \\
(\%)\end{array}$ & Tertiary (\%) \\
\hline 2002 & 8.6 & $\begin{array}{l}\text { Primary/lower } \\
\text { secondary (\%) }\end{array}$ & 37.1 & 11.9 \\
\hline 2003 & 9.1 & 51 & 36.8 & 11.8 \\
\hline 2004 & 10 & 51.4 & 31.4 & 12.2 \\
\hline 2005 & 10.7 & 56.4 & 31.1 & 17.4 \\
\hline 2006 & 11.4 & 51.5 & 29 & 20.6 \\
\hline 2007 & 12 & 50.4 & 33.2 & 25.1 \\
\hline 2008 & 12.7 & 41.7 & 33.5 & 25.9 \\
\hline 2009 & 12.8 & 40.6 & 33.6 & 23.8 \\
\hline 2010 & 13 & 42.6 & 34.8 & 26.9 \\
\hline 2011 & 13.1 & 38.3 & 34.5 & 27.6 \\
\hline 2012 & 13.8 & 37.9 & 36.4 & 27.6 \\
\hline 2013 & 14.4 & 36 & 34.8 & 30.6 \\
\hline
\end{tabular}

Source: ISTAT and Eurostat

For example, if we look at the UK (see Chap. 10), according to the AIRE about 16,000 Italians registered through the local consulates in 2013, but if we consider how many Italians obtained a national insurance number (NIN) in the same year, a mandatory document that allows to work in the UK, then the figure rises to about 44,000. In 2013 the numbers of NIN allocated to Italians was $66 \%$ higher than in the previous year, the largest increase since data is available. The annual inflow of registration is four times higher than its pre-crisis levels. Over $80 \%$ of the Italian that were allocated a NIN in 2013 were below 34 years old. Forty-two percent were aged between 18 and 24, The NIN data, though, incorporate also Italians only by passport, that never actually lived in Italy, mostly Latin Americans of Italian descent that use the Italian nationality to enter the EU labour market freely (Tintori 2011). According to the UK census of 2011, in fact, nearly $10 \%$ of the UK residents holding an Italian passport were born in Latin America. Moreover, the NIN registration is mandatory for temporary and seasonal work too and it is valid for life. Therefore the numbers cannot be used to assume the actual stock of Italians living in the UK and do not tell us much about the length of their stay. On the other side, the NIN registrations do not include Italian people that are not working in the country and yet live there.

In Germany the stock of Italians increased in 2013 at its fastest rate since the 1970s. Over $80 \%$ of Italians (excluding students) living in Germany in 2012 had a degree in secondary/higher education. According to Swiss national statistics the inflow of Italian immigrants was at its peak in 1983, when it reached 12,000 people, it was below 7000 people per year in the decade to 2006, but then it jumped again and reached a record high in 2013 with over 13,000 Italian immigrants. This means that nearly 80,000 Italians officially entered Switzerland with a status of permanent 
resident in the 7 years to 2013 compared to half that size in the previous 7 years. To these figures, we should also add at least 60,000 so-called 'frontalieri' - Italian cross-border workers - who every weekday commute for work between the two countries. Even if we look at less favoured destination countries, Italian emigration appears to be on the rise. In Austria, immigration from Italy grew a 35\% in 2012 over the previous year, the fastest rate since consistent data were made available in 2002. The share of Italian immigrants aged 15-29 years old increased by $6 \%$ points to $49 \%$ between 2008 and 2013. In the Netherlands there is a similar rise of Italian immigration during the years of the crisis, especially of young people. Immigration data from other countries confirm the described trend too (Table 4.2).

An interesting exception is Belgium. Belgium recorded a long-term decline in Italian immigration that has not stopped during the years of the crisis, even if it is slightly milder. This is the result of two factors: a reduction in the influx of Italians since the 1980s - the net Italian migration flow is currently about even; and rising numbers of acquisition of Belgian nationality, which is automatic to third generation children. Despite the decline, though, Italians - together with the French - are still the largest foreign population in Belgium with over 150,000 individuals (Vause 2013; see Chap. 7).

Table 4.2 Stock and \% annual change of Italian residents in Germany, Switzerland, Austria, Belgium, 2001-2013

\begin{tabular}{|c|c|c|c|c|c|c|c|c|}
\hline & $\begin{array}{l}\text { Stock of } \\
\text { Italians in } \\
\text { Germany }\end{array}$ & $\begin{array}{l}\text { Annual } \\
\% \\
\text { change } \\
\end{array}$ & $\begin{array}{l}\text { Stock of } \\
\text { permanent } \\
\text { Italian } \\
\text { resident in } \\
\text { Switzerland } \\
\end{array}$ & $\begin{array}{l}\text { Annual } \\
\% \\
\text { change } \\
\end{array}$ & $\begin{array}{l}\text { Stock of } \\
\text { Italians } \\
\text { in } \\
\text { Austria }\end{array}$ & $\begin{array}{l}\text { Annual } \\
\% \\
\text { change }\end{array}$ & $\begin{array}{l}\text { Stock of } \\
\text { Italians in } \\
\text { Belgium }\end{array}$ & $\begin{array}{l}\text { Annual } \\
\% \\
\text { change }\end{array}$ \\
\hline 2001 & 616,282 & & 313,976 & -1.8 & & & 195,586 & \\
\hline 2002 & 609,784 & -1.1 & 308,255 & -1.8 & 1364 & & 190,792 & -2.5 \\
\hline 2003 & 601,258 & -1.4 & 303,770 & -1.5 & 1461 & 7.1 & 187,021 & -2.0 \\
\hline 2004 & 548,194 & -8.8 & 300,214 & -1.2 & 1402 & -4.0 & 183,021 & -2.1 \\
\hline 2005 & 540,810 & -1.3 & 296,392 & -1.3 & 1380 & -1.6 & 179,015 & -2.2 \\
\hline 2006 & 534,657 & -1.1 & 291,684 & -1.6 & 1467 & 6.3 & 175,498 & -2.0 \\
\hline 2007 & 528,318 & -1.2 & 289,589 & -0.7 & 1713 & 16.8 & 171,918 & -2.0 \\
\hline 2008 & 523,162 & -1.0 & 290,020 & 0.1 & 1842 & 7.5 & 169,027 & -1.7 \\
\hline 2009 & 517,474 & -1.1 & 289,111 & -0.3 & 1955 & 6.1 & 166,956 & -1.2 \\
\hline 2010 & 517,546 & 0.0 & 289,125 & 0.0 & 2167 & 10.8 & 165,052 & -1.1 \\
\hline 2011 & 520,159 & 0.5 & 290,546 & 0.5 & 2297 & 6.0 & 162,826 & -1.3 \\
\hline 2012 & 529,417 & 1.8 & 294,359 & 1.3 & 3095 & 34.7 & 159,727 & -1.9 \\
\hline 2013 & 552,943 & 4.4 & 301,254 & 2.3 & & & 157,426 & -1.4 \\
\hline
\end{tabular}

Source: Statistical office of Germany, Switzerland, Austria and Belgium 


\subsection{Policies and Debates}

The Italian State has traditionally looked at the emigrants and their descendants as commercial and economic outlets and a key instrument for promoting its political role in the international arena (Tintori 2013: 143-146). Even during the period of the so-called 'Great Emigration' at the turn of the twentieth century and again during the second wave of mass emigration after World War II, when Italians were leaving by the millions per decade, the concern about the 'haemorrhage' of economically active population was short-lived. It was quickly replaced by the argument that saw emigration as a safety valve to deal with unemployment and a prospect to establish 'colonies' of consumers of Italian products abroad. More ambitiously, the presence of an Italian diaspora was exploited to project the nation's prestige, economy and labour market internationally (Manzotti 1962; Choate 2008; Tintori and Colucci 2015).

In terms of policy response, the Italian State has historically displayed a high degree of activism in promoting tailor made measures for the citizens abroad and their descendants. Since the 1970 s - to consider the post-war period only - the institutions involved ranged from local level administrations - e.g. Regioni and Comunito governmental departments - e.g. Ministry of Foreign Affairs, of Labour, of the Interior, of the Economy - and ad hoc created public agencies. Provisions varied between economic incentives to return, welfare and pension schemes provided directly abroad, training and educational programs, Italian language schools abroad, and climaxed in 2000-2001 with the adoption of the legislation on external voting that allocated 18 dedicated seats for the external citizens in representation of 4 global electoral macro-districts (Tintori 2013: 140-143; Lafleur 2013: 78-87). In a context of continuity, it is therefore noteworthy to assess whether there has been a shift in the contents and intensity of the Italian State's activities dedicated to the citizens abroad since 2008, as a response to the increase in the outflows of the recent years.

\subsubsection{Public Discourse After the Crisis}

As the first section showed, between 1990 and 2014, with the exception of the 2002-2004 period, the net migration rate of Italian citizens has been negative. This means that, even though its dimension waxed and waned, emigration, already mainstreamed into the narrative of the nation, has not ceased to be a permanent trait of the Italian society, economy and culture. Three main interwoven public discourses dominated the debate regarding recent emigration.

The first, up to the crisis, was mainly proposed by some experts and academics and was quickly adopted in media representations and descriptive, mostly autobiographical essays (Altreitalie 2011; Cucchiarato 2010; Soffici 2014). It described the recent migratory waves as the so-called nuove mobilità ("new mobility"), in order 
to mark the distance from the mass emigration of the past, in that the latter featured humble, unskilled, poorly educated individuals and families forced to leave the country out of sheer misery, with nothing but cardboard suitcases, relying on the chain migration system to find a job at destination; while the former resonates much more with the population of the so-called "Eurostars" (Favell 2008), a generation of highly skilled and intensely mobile people who are equipped to roam between "Eurocities" and global capitals to make the best out of the "human face" of globalization (Favell et al. 2006).

The second, prominent especially after the crisis and the growth in emigration rates, was a further development of the first with a note of pessimism added to it. It is still pivoted on the young and talented, the highly skilled, the graduates, the "best of Italy" (Tirabassi and Del Prà 2014), who would be forced - rather than choose to leave the country in growing numbers, since Italy is ruled by the elderly and they are not offered anything but fixed-term contracts, unrewarding career-prospects, and peanuts-paid jobs. Members of the political elites contributed to this narrative through public statements that prompted nationwide discussions on the brain drain'. For example, in November 2009, Pier Luigi Celli, the dean of the Romebased private University LUISS, funded by the association of Italian entrepreneurs, published an open letter to his son on one of the leading newspapers, La Repubblica, in which he advised him to leave the country as soon as he graduated. ${ }^{3}$ By the same token, Fabrizio Barca, then minister of Mario Monti's government, declared in 2012 that leaving the country was the right choice for young graduates, citing the example of two out of three of his sons that had started a career in Latin America and in the UK. ${ }^{4}$ As a result, this explicit, almost exclusive focus on talent and emigration of graduates through the media, popular blogs ${ }^{5}$ and the political elites, has popularized the phrase 'fuga dei cervelli' - the Italian equal for brain drain -, which is applied indiscriminately to every (relatively) young Italian who goes overseas, regardless of their qualification and occupation.

This only partially true and extremely over-simplistic rendition of Italy's current mobility patterns, even in the academic realm, relies essentially on qualitative and human-centred empirical research that samples on the dependent variable. It does not delve into the actual data on the human capital of those who leave, their occupation, wage levels, type of job contracts, and length of stay abroad. As we have only started to demonstrate in the first part of the chapter, though, if there is enough evidence to state that the recent rise of emigration - especially that undetected by Italian official data - was significantly composed of young people, there are no solid

\footnotetext{
${ }^{3}$ Pier Luigi Celli, "Figlio mio, lascia questo Paese", La Repubblica, 30 November 2009. http:// www.repubblica.it/2009/11/sezioni/scuola_e_universita/servizi/celli-lettera/celli-lettera/celli-lettera.html; last accessed 13 August 2014.

4 “Barca: 'Fuga di cervelli? Se Italia non migliora è giusta"”, La Repubblica, 16 April 2012, http:// www.repubblica.it/scienze/2012/04/16/.../barca_fuga_di_cervelli_se_italia_non_migliora_ giusta-33394354/; last accessed 17 April 2014.

${ }^{5}$ Among the most popular blogs are Italians by Beppe Severgnini, journalist of one of the most important Italian newspapers, Il Corriere della Sera, and Giovani Talenti (Young talents) hosted by Sergio Nava, journalist of the main economic Italian newspaper Il Sole 24Ore.
} 
proofs that they bring the 'brain' too with them, as they are not necessarily skilled or they don't necessarily end up working in highly-skilled sectors. In the next and final section, we will add a few more words on the issue, by looking at the data on the human capital of those who have left or might leave.

Third discourse: the principal Italian daily newspapers, the liberal La Repubblica and the moderate Il Corriere della Sera, have joined the 'brain drain frenzy' and feature regular contributions, in their online versions especially, that spotlight the 'haemorrhage' of the best part of the population. ${ }^{6}$ This kind of reportages has often been associated to the difficulties that Italy faces in integrating her immigrants. Probably an unintended outcome, the alarmed tones characterizing these discourses have led to a political climate where an 'Italians first' argument and an antiimmigrant backlash have become politically legitimate, even more so in the context of growing competition for jobs. Thus, not only the traditionally anti-immigrant campaigns of the Northern League are now recrudescing, but also the minister of the Interior, Angelino Alfano, member of the broad coalition government led by Matteo Renzi, recently declared that the government will not allow that even "a single immigrant take the job of an Italian citizen". ${ }^{7}$

\subsubsection{Political Initiatives}

The long-standing dynamism of the Italian state towards the 'Italians abroad', a phrase that indistinctly conflates both the emigrants and the descendants of former emigrants, makes it difficult to single out which policies and/or agencies have been developed as a reaction to the growth of outflows after the crisis. In addition, in the course of - even recent - history, a plethora of institutions have been in charge to deal with the 'Italians abroad'. In this section, we provide a first review of the measures undertaken since 2008. We examine whether there has been a shift in the contents and intensity of the governmental activities towards the emigrants, if these measures are dependable on the described public discourses that accompanied the recent outflows, and whether they are consistent with the available data on 'those who leave', Italy's economic situation and labour market.

Since the 1990s, and even more intensely between 2000 and 2007, virtually all of the 20 Italian regional administrations passed legislative acts that reached out for their reference communities of 'Italians abroad'. Provisions encompassed a wide range of policies: social subsidies, vocational training and co-development projects, programmes aimed at facilitating 'co-ethnic' returns, cultural exchange trips, tourism, and so forth. After the crisis, a minority of experts and politicians, especially

\footnotetext{
${ }^{6}$ See, for example, the ad hoc created video-reportage format Domicilio Londra (Domicile: London) by La Repubblica: http://video.repubblica.it/rubriche/domicilio-londra

7 “Alfano: 'Non accetteremo che un immigrato prenda il posto di un italiano', La Repubblica, 1 August 2014, http://www.repubblica.it/politica/2014/08/01/news/alfano_-92937945/: last access 2 August 2014.
} 
those with an academic background, assuming a high degree of return or circularity of the current outflows have tried to frame the 'Italians abroad' question mainly as an opportunity and not necessarily as a problem, a potential occasion to further develop the labour force's human capital, improve the balance of trade and of payments, and a chance to transform the 'brain drain' into a 'brain return' (ISPI 2012). A more systematic study is still needed, but it seems that more recently the main efforts of both state-level agencies and local administrations have been directed, on the one hand, towards the establishment of ethnic business communities and, on the other, towards the return of individuals with improved human and social capital.

As recently as 30 December 2010, the then Berlusconi's government approved a measure (Law 238) formally aimed at attracting EU skilled citizens to move and work in Italy. The law grants tax incentives to EU citizens born after 1969, who have been working or have graduated abroad but have resided for at least 2 years in Italy in the past. The incentives are accorded if they start new business activities in Italy or are hired permanently by an Italian employer. As a matter of fact, the law is primarily targeting Italian nationals, as an attempt to pave the way for the return of the skilled and young emigrants. In fact, the measure, which is advertised in Italian only, includes a series of ancillary privileges for Italian citizens alone, in terms of access to public housing and pension benefits. It also creates a privileged bureaucratic channel for the Italian applicants in order to speed up their procedures, through a collaboration between the Italian consulates and the agency Italia Lavoro SpA, created in 1997 and controlled by the Ministry of the Economy. Incidentally, these actions were undertaken concurrently with the adoption of policies that retrenched the social and economic rights of third country nationals regularly residing in Italy and made more demanding the procedures to get their residence permits renewed.

The 2010 Law and the hegemonic narrative on the 'brain drain' became the foundation of ensuing actions taken both at the local and state level. The Umbria region has launched the programme 'Brain Back Umbria', which further develops its Regional Law 37 of 1997. The programme, financed mainly through the European Social Fund, focuses exclusively on former residents of the region living abroad. It grants tax incentives for new businesses and start-ups set up in the region, as well as seed money - 5000 Euros - for researchers. ${ }^{8}$ Similarly, the municipality of Milan has launched the portal "Welcome Talent", in cooperation with the blog Italents and few local scholars. The programme, through the action called "Welcome Business", allocated 510,000 Euros to 'talented returnees' in order to start a new business in Milan. In 2012, under Monti's government, the Ministry of the Interior and the Ministry of Education activated the platform "Innovitalia" whose goal is to "maximise the impact of human capital" of the Italian "brains" abroad and "promote research and business opportunities" in partnership with the motherland. ${ }^{9}$

These actions are certainly consistent with the hegemonic narratives concerning the current emigration, where both the governmental rhetoric and media reports

\footnotetext{
${ }^{8} \mathrm{http}: / / \mathrm{www} \cdot$ brainbackumbria.eu/index.php last access 12 August 2014.

${ }^{9} \mathrm{http}: / / \mathrm{www}$. innovitalia.net/crowdforce/product/index.html last access 12 August 2014.
} 
insist on the presence of graduates. Yet, the available data show that the percentage of graduates, though on the increase, is by far a minority not only in the stock but also in the yearly emigrant population.

In some respects, Italy presents all the prerequisites for suffering from a 'brain drain' issue. Education did not help much to avoid economic distress. Unemployment rates among those with a tertiary education were about $11.5 \%$ of the young population (25-34 years old) in 2011, an even larger proportion than among those with secondary education $(10.5 \%)$ and not so smaller than the unemployment rate of those without education $(14.8 \%)$. In other countries, university degrees are much more rewarding in terms of employability. For example, in Germany youth unemployment rates drop from $20 \%$ among those with no qualification to $2.7 \%$ among those with a tertiary degree. France shows a similar gap (23\% vs. 6\%) and even in Spain where unemployment rates are higher, earning a degree makes a decisive difference in the labour market (33\% with no qualification vs. $16 \%$ among graduates) (OECD 2013a).

On the other hand, comparative studies show that Italy does not export more graduates than other developed countries - in the EU, for example, Germany, France and the UK have higher percentages of graduates leaving the country - but has instead a problem of 'brain circulation', in that it is not able to attract significant numbers of educated foreigners (Franzoni et al. 2012; Beltrame 2007). The asymmetric treatment reserved to the 'Italians abroad' and third country nationals in the allocation of rights and access to incentives might play a decisive role here. In addition, Italy might not export many graduates as expected simply because, first, there are not so many and, second, they may not be necessarily fit to participate in the global labour market. Italy ranked second to last for tertiary educational attainment among all OECD countries - only Turkey had worse rates - regardless of whether the whole population was considered or only the youth cohort (25-34 years old) (OECD 2013b). By the same token, in 2013 Italy scored poorly, last place among 20 OECD countries, for percentage of adults (aged 16-65) who worked in skilled occupations during the previous 5 years (OECD 2013c: 442). Enrico Giovannini, then minister of Labour in Letta's government, commenting on these data, bitterly observed that the average poor human capital of most of the Italian young people made them simply unemployable, when it came to the demands of the international labour market. ${ }^{10}$

Italian consulates have probably a better pulse of the kind of emigration that is taking place from Italy. Massimiliano Mazzanti, the Italian consul in London, confirmed that the UK is a booming destination for Italians looking for a job. Their profiles and qualifications vary extensively, but only a minority ends up working in the City or in highly skilled occupations. As a matter of fact, a growing number of scams have been reported, in which Italian newcomers are requested payment for

\footnotetext{
10 "Giovannini su dati Ocse: 'Dimostrano che italiani poco occupabili'”, La Repubblica, 9 October 2013, http://www.repubblica.it/scuola/2013/10/09/news/giovannini_su_dati_ocse_dimostrano_ che_italiani_poco_occupabili-68246867/ last access 12 August 2014.
} 
accommodation and access to work by fellow citizens and locals ${ }^{11}-$ a sort of historic recurrence of the ethnic-broker or padrone system that accompanied Italy's great emigration of the past. That is why the consulate, in January 2014, launched the "Primo Approdo" (First Landing) project, which offers a downloadable handbook as well as in person meetings with experts to provide young Italians with information on how the labour market, the educational, social, health and legal systems function in the UK. Even more recently, the Italian consulate in Melbourne has hosted a photographic exhibition at the local Museo Italiano, significantly titled What I have to do/What I would like to do, by Cristian Iotti. The exhibit witnesses the stories of many young Italians who have recently arrived in Australia and have adapted to all kind of occupations in order to make a living, while still pursuing their individual dream-job.

\subsection{Conclusion}

There is a clear and growing trend of Italians emigrating from the country after the economic crisis. The figure on emigration of 2014, the highest since the mid-1970s, counts for 1.4 emigrants for every 1000 of the Italian population. As described in the first section of the chapter, numbers, composition, profile and duration of the most recent and current outflows from the country are still somehow uncertain. Yet, they are undoubtedly not comparable in size - both in absolute and relative numbers - with mass departures of the two waves of the historical great emigration. There are enough data to affirm that it is mostly the young to emigrate, as it is usually the case, but there is no solid evidence yet to assert that the majority are also highly-skilled or - educated. Partially, emigration of the young is due to the increased movements of people in a globally interconnected labour market. But the most likely explanations to account for the increase in the emigration rate after the crisis should be sought in the combined effect of two factors: the long period of sluggish or no growth of the economy since the 1990s, which has progressively impoverished the country's household incomes, and the latest labour market reforms, that between 2003, with the law n. 276 of 20 September, and 2012, with the law n. 92 of 8 June, - the so-called Biagi and Fornero Laws, respectively - have heavily deregulated the labour market and introduced flexibility. The reforms, in particular, have a direct responsibility in pushing young people out of the country, since they have aggravated the labour system's segmentation, in which a relevant part of Italy's workforce, with a majority of males and members of the older generations, holds hyper-protected life-long contracts, while a sizeable minority, virtually all of the new employed, has access almost exclusively to insecure, highly-flexible, low-paid jobs (Berton et al. 2012; Simoni 2009). There where more detailed data on

\footnotetext{
11 “Interview with Italian Consul in London, Massimiliano Mazzanti”, L'ItaloEuropeo, 21 February 2014, http://www.italoeuropeo.com/interviews/1539-interview-with-italian-consul-in-london-massimiliano-mazzanti last access 12 August 2014.
} 
the occupation of current Italian emigrants are available and as testified by recent initiatives undertaken by the Italian consular authorities, the hegemonic narratives focussed on the 'brain drain' issue and the export of talents appear to be misleading. They should, at best, speak of 'brain waste'. In fact, on the national labour market front, Italy is not able to participate in the brain circulation system and attract a number of skilled immigrants sufficient to match the relatively average percentage of her graduates and $\mathrm{PhDs}$ that are leaving. It does not reward adequately the young and educated either, who are very often confined to unattractive careers, underpaid and underemployed. On the international labour market front, Italian adults lack the key skills to compete with their peers, constantly ranking in the last place in Europe in terms of foreign languages, numeracy and ICT proficiency (OECD 2013c). Despite these evidences, the public discourse on emigration has adopted quite alarmed tones, since it has focused primarily on the 'brain drain' issue. More worryingly, it has become a field where to display ethno-nationalist arguments and antiimmigrant backlash.

\section{References}

Altreitalie. (2011) Special Issue "Le nuove mobilità", 43.

Ballestrero, M. V. (2012). Declinazioni di flexicurity. La riforma italiana e la deriva spagnola. Lavoro e Diritto, 26(3-4), 441-464.

Beltrame, L. (2007) Realtà e retorica del brain drain in Italia. Stime statistiche, definizioni pubbliche e interventi politici. Trento, Università di Trento, Dipartimento di sociologia e ricerca sociale: Quaderno 35.

Berton, F., Richiardi, M., \& Sacchi, S. (2012). The political economy of work security and flexibility. Italy in comparative perspective. Bristol: The Policy Press.

Carinci, M. T. (2012). Il rapporto di lavoro al tempo della crisi: modelli europei e flexisecurity "all'italiana" a confronto". Giornale di diritto del lavoro e di relazioni industriali, 136, 527-572.

Choate, M. I. (2008). Emigrant nation. The making of Italy abroad. Cambridge, MA: Harvard University Press.

Ciocca, P. (2007). Ricchi per sempre? Una storia economica d'Italia (1796-2005). Turin: Bollati Boringhieri.

Ciocca, P. (2010). La specificità italiana nella crisi in atto". Moneta e Credito, 63(249), 51-58.

Cucchiarato, C. (2010). Vivo altrove. Giovani e senza radici: gli emigranti italiani di oggi. Milan: Bruno Mondadori.

Eurostat. (2013). In 2012, a quarter of the population was at risk of poverty or social exclusion. Newsrelease 184/2013.

Eurostat. (2015). EURO area unemployment rate at 11.4\%. Newsrelease 20/2015.

Favell, A. (2008). Eurostars and Eurocities. Free movement and mobility in an integrating Europe. Oxford: Blackwell Publishing.

Favell, A., Smith, M. P., \& Recchi, E. (Eds.). (2006). The human face of global mobility: International higly skilled migration in Europe, North America and Asia Pacific. New Brunswick: Transaction.

Franzoni, C., Scellato, G., \& Stephan, P. (2012). Foreign born scientists: Mobility patterns for sixteen countries (NBER Working Paper 18067).

ISPI (Istituto per gli studi di Politica Internazionale) (Ed.). (2012). La risorsa emigrazione gli italiani all'estero tra percorsi sociali e flussi economici, 1945-2012 (Report n. 60). Rome: Senato della Repubblica. 
ISTAT. (2014) Migrazioni internazionali e interne della popolazione residente - Anno 2013. Istat Annual Report 9 December 2014.

ISTAT. (2015). Demographic indicators. Estimates for the year 2014. Report, 12 February 2015.

Lafleur, J.-M. (2013). Transnational politics and the state. The external voting rights of diasporas. New York: Routledge.

Manzotti, F. (1962). La polemica sull'emigrazione nell'Italia unita: fino alla prima guerra mondiale. Milan: Dante Alighieri.

OECD. (2011). International migration outlook 2011. Paris: Sopemi - OECD Publishing.

OECD. (2013a). Education at a glance 2013: OECD indicators. Paris: OECD Publishing.

OECD. (2013b). Educational attainment. In OECD factbook 2013: Economic, environmental and social statistics (pp. 188-189). Paris: OECD Publishing.

OECD. (2013c). OECD skills outlook 2013: First results from the survey of adult skills. Paris: OECD Publishing.

Simoni, M. (a cura di) (2009). URG! Urge ricambio generazionale, Rubbettino, Soveria Mannelli.

Soffici, C. (2014). Italia yes, Italia no. Che cosa capisci del nostro paese quando vai a vivere a Londra. Milan: Feltrinelli.

Tiffin, A. (2013). European productivity, innovation and competitiveness: The case of Italy (International Monetary Fund Working Paper, 14/79).

Tintori, G. (2009). Fardelli d'Italia? Conseguenze nazionali e transnazionali delle politiche di cittadinanza italiane. Rome: Carocci.

Tintori, G. (2011). The transnational political practices of 'Latin American Italians'. International Migration, 49(3), 168-188.

Tintori, G. (2012). More than one million individuals got Italian citizenship abroad in twelve years (1998-2010). EUDO Citizenship News, 21 November.

Tintori, G. (2013). Italy: The continuing history of emigrant relations'. In M. Collyer (Ed.), Emigration nations. Policies and ideologies of emigrant engagement (pp. 126-152). Basingstoke: Palgrave Macmillan.

Tintori, G., \& Colucci, M. (2015). From manpower export to brain drain? Emigration and Italy, between past and present'. In A. Mammone, E. Giap Parini, \& G. Veltri (Eds.), Routledge handbook of contemporary Italy: History, politics, and society (pp. 37-48). New York: Routledge.

Tirabassi, M., \& Del Prà, A. (2014). La meglio Italia. Le mobilità italiane nel XXI secolo. Turin: Accademia University Press.

Vause, S. (2013). Migrations et populations issues de l'immigration en Belgique. Rapport statistique et démographique 2013. Louvain: Centre de Recherche en démographie et sociétés (DEMO).

Open Access This chapter is licensed under the terms of the Creative Commons AttributionNonCommercial 2.5 License (http://creativecommons.org/licenses/by-nc/2.5/), which permits any noncommercial use, sharing, adaptation, distribution and reproduction in any medium or format, as long as you give appropriate credit to the original author(s) and the source, provide a link to the Creative Commons license and indicate if changes were made.

The images or other third party material in this chapter are included in the chapter's Creative Commons license, unless indicated otherwise in a credit line to the material. If material is not included in the chapter's Creative Commons license and your intended use is not permitted by statutory regulation or exceeds the permitted use, you will need to obtain permission directly from the copyright holder.

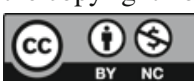

